\title{
42. 数種の両耳補聴器装着時の方向覚について
}

\author{
白岩 拨雄・向井敬・大角昌彥 \\ 大谷 晃一・風本 途也*
}

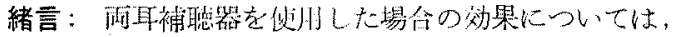

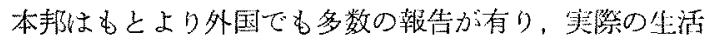

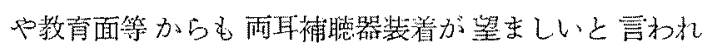
る。我々は，正常者と片側難聴者（平均聴損 $30 \mathrm{db}$ 以 上）について，裸耳の場合を対象として，閶席や传度の 堂らマイクロフォンを桷えた数種の雨耳補聴器を装着し た場合の方向覚飞ついて央験的観察を行い，2，3の成 績を得たので影告する。

装置及び方法：筷鈳は東京医大の防音公内で行つた。 被唡者は遮眼させ，頭部を固定し正面位で椅座させた。 正誤の判定は被検者の口答法によつた，検査点は被検者 の前力卓上に固定したリオン試作の両耳蜅鳃器のマイク ロフォン面を中心に半径 $1 \mathrm{~m}$ の半円を画き， $90^{\circ}$ 前方 (A) 及びマイクロフォン面より $22.5^{\circ}$ 左存の点（B）, (C) の3点を採つた（图1 及び図2)，襟耳の場合は頭

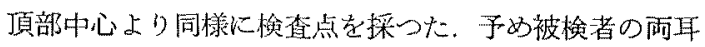
に補㯖器をつけさ山，快適聴取レベルに調整し，左右 の意の大いさを等しくした。この場合正常耳及び正常

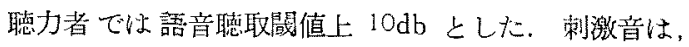

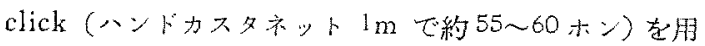
い, 検者が手で操作し，3個の click 刺漖を然作為に各 点で 5 回被検渚に与光て正答率を求めた。両耳補聴器は

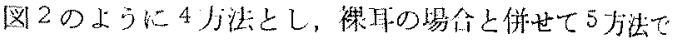

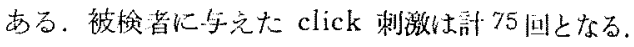

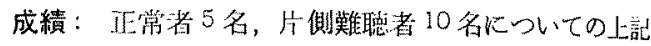
实駼の成績は表 1 の通りである。統計的観察儿は平均值 と標隼偏差より备方法閏の有意性の检定を下式に上り仵 隃集 5\%で求めた。

$$
\mathrm{t}_{0}=\frac{\overline{\mathrm{x}}-\overline{\mathrm{y}}}{\mathrm{w}} \cdot \sqrt{\frac{\mathrm{N}}{2}}, \mathrm{n}=2 \mathrm{~N}-2
$$

裁 2 のよに(1)上(5), (2)と(3)及び(2)と(4)の各方法の間で は有意の盖梳ありないようである，その他の各法の間 では少くとも有意の差が認められる。裸耳についで6法 が最も正答率が良いことを知つた。

結論：例数が少なくはつきりしたことは言竞ないが，

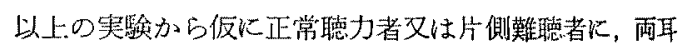
に補聴器をつけさせた場合では，万向覚は裸耳に次いで

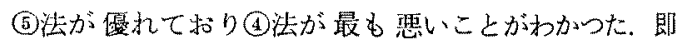

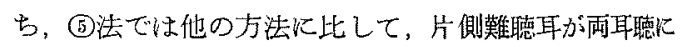
和ける力向賞について少なくともある程度役立つている と思扣扎る，今後は検查音を種類を变劣て，两側難㯖者

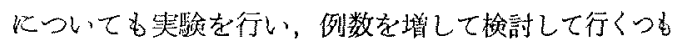
りである。

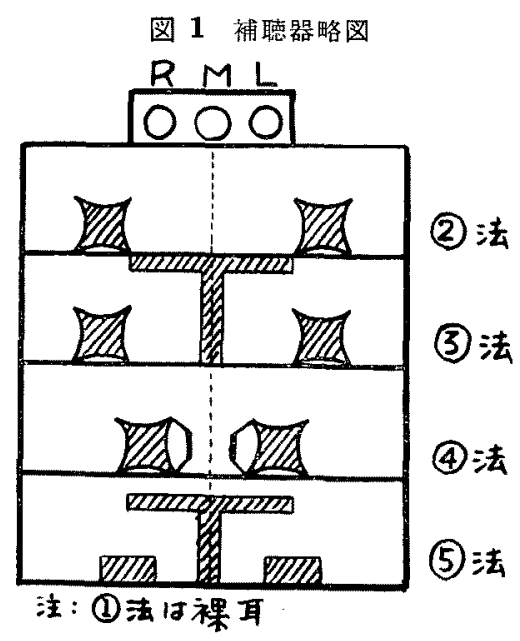

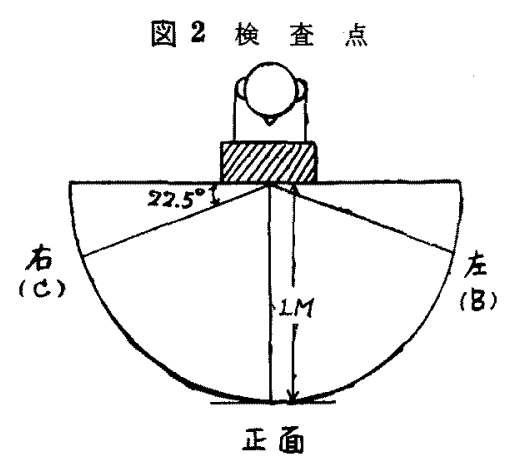

(A) 
表 1 被粭者の正答率（\%)

\begin{tabular}{|c|c|c|c|c|c|c|c|c|}
\hline \multirow{2}{*}{ 症例 } & \multirow{2}{*}{ (1)法 } & \multirow{2}{*}{ (2)法 } & \multirow{2}{*}{ (3)法 } & \multirow{2}{*}{ (4)法 } & \multirow{2}{*}{ (5)法 } & \multicolumn{3}{|c|}{ ダイヤル目盛 } \\
\hline & & & & & & Right & Main & Left \\
\hline $\mathrm{A}$ & 100 & 73 & 80 & 67 & 100 & 0 & 1 & 0 \\
\hline$B$ & 100 & 67 & 67 & 73 & 93 & 0 & 1 & 0 \\
\hline $\mathrm{C}$ & 100 & 47 & 67 & 27 & 73 & 0 & 1 & 0 \\
\hline $\mathrm{D}$ & 100 & 53 & 53 & 13 & 67 & 0 & 1 & 0 \\
\hline $\mathrm{E}$ & 100 & 73 & 73 & 53 & 80 & 0 & 1 & 0 \\
\hline $\mathrm{F}$ & 87 & 47 & 67 & 40 & 80 & 2 & 1 & 0 \\
\hline $\mathrm{G}$ & 60 & 87 & 80 & 60 & 93 & 2 & 1 & 0 \\
\hline $\mathrm{H}$ & 93 & 67 & 60 & 40 & 93 & 4 & 1 & 0 \\
\hline 1 & 100 & 47 & 73 & 53 & 93 & 0 & 1 & 3 \\
\hline $\mathrm{J}$ & 93 & 93 & 80 & 73 & 87 & 0 & 1 & 2 \\
\hline $\mathrm{K}$ & 100 & 87 & 80 & 60 & 87 & 0 & I & 3 \\
\hline $\mathrm{L}$ & 93 & 53 & 53 & 47 & 80 & 2 & 1 & 4 \\
\hline $\mathrm{M}$ & 53 & 67 & 67 & 53 & 60 & 7 & 1 & 0 \\
\hline $\mathrm{N}$ & 80 & 47 & 47 & 47 & 40 & 0 & 1 & 9 \\
\hline 0 & 87 & 87 & 87 & 100 & 100 & 0 & 1 & 6 \\
\hline & & & & & & & & \\
\hline
\end{tabular}

表 2 各法闻の有意性椮定

\begin{tabular}{|c|c|c|c|}
\hline & & $t_{0}$ & \\
\hline (1) (2) & 閶 & 4.216 & + \\
\hline (1) (3) & {$\left[{ }^{[}{ }^{6}+\right]$} & 4.162 & $t$ \\
\hline (1) (4) & 措 & 5.498 & + \\
\hline (1) (5) & 間 & 1.846 & - \\
\hline (2) (3) & {$\left[y^{2}\right.$} & 0.944 & - \\
\hline (2) (4) & 䦧 & 1.389 & - \\
\hline (2) (5) & 間 & 3.053 & $t$ \\
\hline (3) (4) & 間 & 2.476 & + \\
\hline (3) (9) & 間 & 2.713 & + \\
\hline (4) (5) & 間 & 4.336 & + \\
\hline
\end{tabular}

